\title{
Simultaneous Viral Infection and Childhood Bronchiolitis Obliterans
}

\author{
Mário Hirschheimer, Paulo S. L. Silva, \\ Roseli Giudici, Milene Carrilho, Thais Mauad \\ and Maria Ishida
}

\author{
Menino Jesus São Paulo City Children's \\ Hospital, São Paulo;Pediatric Clinic of the \\ Servidor Público Municipal de São Paulo \\ Hospital; Federal University of São Paulo, \\ Department of Pathology of the University of \\ São Paulo; Adolfo Lutz Institute, São Paulo, SP, Brazil
}

\begin{abstract}
Lower respiratory tract infections by respiratory syncytial virus (RSV) are frequent in childhood. Association of RSV with bronchiolitis obliterans has rarely been established. We report a 13-month-old child with bronchiolitis obliterans following co-infection by RSV and adenovirus, and suggest that complicated evolution of an acute bronchiolitis case can indicate an association of pathogens.

Key Words: Acute bronchiolitis, adenovirus, bronchiolitis obliterans, co-infection, lower respiratory tract infections, respiratory syncytial virus.
\end{abstract}

In children, bronchiolitis obliterans $(\mathrm{BO})$ is preceded, in most cases, by a lower respiratory tract infection, with viral acute bronchiolitis being the most frequent precursor, mainly caused by adenovirus types 3,7 and 21 [1-7]. Other viruses (RSV, parainfluenza 2 and 3 , influenza $\mathrm{A}$ and $\mathrm{B}$, rubella and measles virus) and bacteria (Mycoplasma, Bordetella and Streptococcus type B) have also been implicated as etiological agents in some cases of $\mathrm{BO}$ [8-10]. Currently, there is no epidemiological information regarding the prevalence of BO in the infant population in Brazil. Clinical observations suggest that the prevalence of this disease is higher than was previously postulated $[4,8,11]$.

\section{Case Report}

A 13-month-old male infant was admitted in the paediatric ICU with a 4-day history of fever and Received on 06 March 2002; revised 05 May 2002.

Address for correspondence: Dr.Dr. Mário Roberto Hirschheimer. Rua Indiana ${ }^{\circ} 337$, apto. 51 - Brooklin, São Paulo - SP - Zip Code: 04562-000. Phone: (11) 5543-6653Fax:(11)5561-7360.E-mail:msfsh@ajato.com.br

The Brazilian Journal of Infectious Diseases 2002;6(3):146-148 (C) 2002 by The Brazilian Journal of Infectious Diseases and Contexto Publishing. All rights reserved.

$1413-8670$ dyspnea, worsening 24 hours before admission. He had been treated one month earlier with a 10-day course of amoxicillin and salbutamol due to a diagnosis of bronchopneumonia and bronchospasm. On physical examination, the vital signs were as follows: respiration, 50 breaths/min; pulse, 166 beats/min; blood pressure, $110 / 60 \mathrm{mmHg}$; and temperature, $36.5^{\circ} \mathrm{C}$. Cardiac, abdominal and neurological findings were normal. Pulmonary examination revealed moderate breathing distress (Wood Score, 4) [12], moderate intercostal and subdiaphragmatic retraction, disseminated inspiratory and expiratory wheezing and subcrepitant rales at lung bases. Laboratory findings were as follows: WBC count, $8,100 / \mathrm{mm}^{3}$, normal arterial gases $\left(\mathrm{FiO}_{2}\right.$ $=40 \%$ ) and blood electrolytes. Chest roentgenogram showed lung hyperinflation with bilateral interstitialalveolar infiltration and condensation in $2 / 3$ of the right superior lobe. Treatment with intravenous oxacillin and chloramphenicol, terbutaline in continuous infusion $(0.6$ to $2.5 \mathrm{mg} / \mathrm{kg} / \mathrm{min}$ ) and methylprednisolone (4 mg/ $/ \mathrm{kg} /$ day) was started. During the following days the patient had no fever but dyspnoea persisted. Blood cultures were negative. Indirect immunofluorescence assay for rapid diagnosis of the nasopharyngeal aspirate was positive for RSV and negative for influenza virus types $\mathrm{A}$ and $\mathrm{B}$, adenovirus and parainfluenza virus types 1,2 
Figure 1. Histological picture of constrictive type BO. There is peribroncholar chronic inflamation and mild fibrosis. The airway lumen is narrowed. $\mathrm{H} \& \mathrm{E} 100 \mathrm{X}$

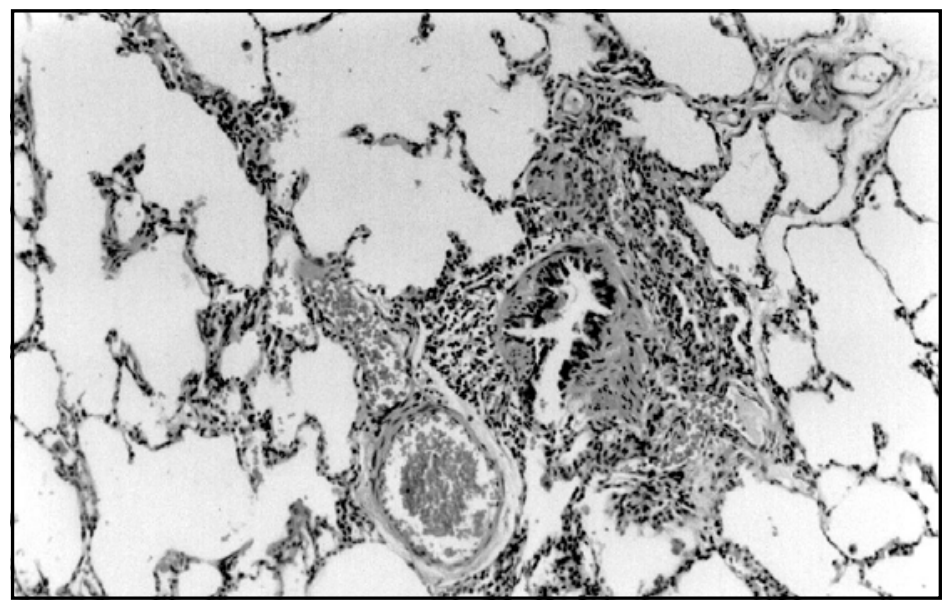

and 3. The results of serology for respiratory virus on the 5 th and the 20th day are shown in Table 1 . On the 9th hospital day the patient's respiratory status worsened further (Wood Score, 6), and the patient was submitted to mechanical ventilation, which lasted 120 days. CT scan of the thorax at day 45 revealed bronchiectasis of the right lung, atelectasis and mixed images of hypo and hyperattenuation (mosaic pattern). At day 125, an open lung biopsy was performed. Histological analysis revealed a constrictive type BO (Figure 1) with parenchyma hyperdistension and vascular thrombosis, associated with a foreign-body type granulomatous reaction in the arteriole walls. Sweat electrolytes and immunoglobulins were normal. Mycoplasma and HIV serology were negative. The search for hemossiderin-laden macrophages and fast acid bacilli in early morning gastric lavages, after overnight fasting, came up negative. The tuberculin skin test was $<5$ millimetres. An echocardiographic exam demonstrated severe pulmonary hypertension. The patient was discharged after 210 days of hospitalisation and maintained on inhaled corticosteroids, as well as broncho and vasodilators.

\section{Discussion}

Acute bronchiolitis is the most frequent lower respiratory tract disease in infancy. About $1 \%$ of the
Table 1. Serological tests for RSV and adenovirus (not typed)*

\begin{tabular}{lcc}
\hline & RSV & Adenovirus \\
\hline 1st sample & $1: 64$ & $1: 64$ \\
2nd sample & $>1: 128$ & $\geq 1: 502$ \\
\hline * Indirect immunofluorescence quantitative method using RSV \\
and adenovirus antigen produced by HEp2 cell culture \\
laryngeal carcinoma cells). It is considered positive when there \\
is a fourfold increase using samples collected two weeks apart.
\end{tabular}

patients develop post-infectious BO [9]. Respiratory syncytial virus (RSV) is the most frequent causal agent, mainly during the winter months. An association between RSV infection and BO has rarely been reported, however [17]

This patient had a simultaneous infection by RSV and adenovirus, confirmed by detection of the RSV antigen in respiratory secretions and a serological test, respectively. The low sensibility for the detection of adenovirus in nasopharyngeal secretions is probably due to the limited amount of adenovirus antigens in the epithelial cells from the nasopharynx [13]. Other investigators have reported the simultaneous finding of more than one pathogen in viral infected patients [1416]. After a Medline revision starting in 1966, we observed that in the medical literature concerning childhood BO, there is just one report [17] referring this same association. The authors of this work 
credited an adenovirus as the principal agent responsible for the development of BO in their patient. Tristram and Miller [18], however, reported that simultaneous infection of RSV and other respiratory tract pathogens promotes a more severe evolution of infection, observing that co-infection by RSV and adenovirus was associated with severe respiratory failure and death (three deaths in four patients).

Possibly, the simultaneous occurrence of two viral pathogens was responsible for the complicated evolution of the bronchiolitis in this patient. The open lung biopsy considered as "gold standard" for diagnosis of BO $[4,19]$ was indicated because of his progressive respiratory deterioration in spite of therapeutics [4]. Constrictive type $\mathrm{BO}$ is characterized by different degrees of peribronchiolar inflammation and fibrosis, and it is the most frequent histological type of BO found in children. In summary, we have described an unusual association of adenovirus and RSV as etiological agents of childhood BO. Our report focuses attention on a possible relation between pathogen association and severe or complicated evolution of lower respiratory tract infections.

\section{References}

1. Lang W.R., Howden C.W., Laws J., Burton J.F. Bronchopneumonia with serious sequelae in children with evidence of adenovirus type 21 infection. Brit Med J 1969; 1:73-9.

2. Becroft D.M.D. Bronchiolitis obliterans, bronchiectasis and other sequelae of adenovirus type 21 infection in young children. J Clin Pathol 1971;24:72-82.

3. Gold R., Wilt J.C., Adhikari P.K., MacPherson R. Adenoviral pneumonia and its complications in infancy and childhood. J Can Assoc. Radiol 1969;20:218-24.

4. Hodges I.G.C., Milner A.D., Groggins R.C., Stokes G.M. Cause and management of bronchiolitis with chronic obstructive features. Arch Dis Child 1982;57:495-9.

5. Omar A.H., Manan A. Bronchiolitis obliterans in children. A report of six cases. Med J Malaysia 1989;44:204-9.

6. Wohl M.E.B, Chernick V. Bronchiolitis. Am Rev Respir Dis 1978; $118: 759-81$.

7. Simila S., Linna O., Lanning P., et al. Chronic lung damage caused by adenovirus type 7: Ten-year follow-up study. Chest 1981;80:127-31.
8. Hardy K.A., Schidlow D.V., Zaeri N. Obliterative bronchiolitis in children. Chest 1988;93:460-6.

9. Milner A.D., Murray M. Acute bronchiolitis in infancy: treatment and prognosis. Thorax 1989;44:1-5.

10. Mayock D.E., Rourke P.P., Kapur R.P. Bronchiolitis obliterans: a complication of group B streptococcal disease treated with extra-corporeal membrane oxygenation. Pediatrics 1993;92:157-9.

11. Zhang L., Irion K., Kozakewich H., et al. Clinical course of postinfectious bronchiolitis obliterans. Pediatr Pulmonol 2000;29:341-50.

12. Wood D.W., Downes J.J., Scheinkopf H. Intravenous isoproterenol in the management of respiratory failure in childhood status asthmaticus. J Allergy Clin Immunol 1972;50:75.

13. Gardner P.S., Mcquillin J. Rapid virus diagnosis: Applications of immunofluorescence $-2^{\text {nd }} \mathrm{Ed}$, London, Butterworths, 1980:195-200.

14. Nichol K.P., Cherry J.D. Bacterial-viral interrelations in respiratory infections of children. N Engl J Med 1967;22:667-2.

15. Hilleman M.R., Hamparian V.V., Ketler A., et al. Acute respiratory illnesses among children and adults: Field study of contemporary importance of several viruses and appraisal of literature. JAMA 1962;180:445-52.

16. Waner J.L., Whitehurse N.J., Jonas S., et al. Isolation of viruses from specimens submitted for direct immunofluorescence test for respiratory syncytial virus. J Pediatr 1986; 108:249-50.

17. Massie R., Armstrong D. Bronchiectasis and bronchiolitis obliterans post respiratory syncytial virus infection: think again. J Paediatr Child Health 1999; 35(5):497-8.

18. Tristram D.A., Miller R.W., MacMillan J.Á., Weiner L.B. Simultaneous infection syncytial virus and other respiratory pathogens. Am J Dis Child 1988; 142(8): 834-6.

19. Hardy K.A. Childhood bronchiolitis obliterans. In: Epler GR (Ed). Diseases of the bronchioles. New York: Raven Press; 1994:415-26. 